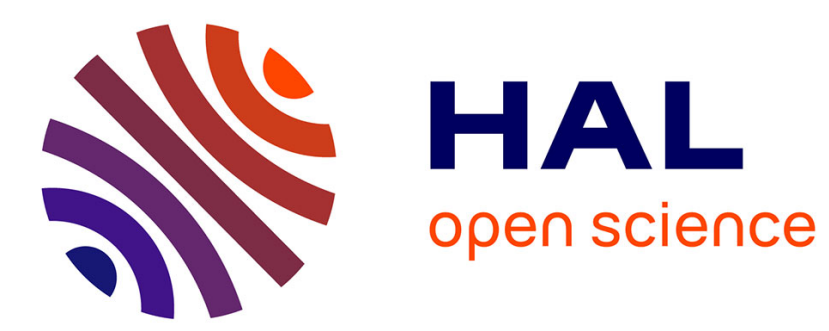

\title{
Blood cigarettes: cigarette smuggling and war economies in central and eastern Africa
}

Kristof Titeca, Luk Joossens, Martin Raw

\section{To cite this version:}

Kristof Titeca, Luk Joossens, Martin Raw. Blood cigarettes: cigarette smuggling and war economies in central and eastern Africa. Tobacco Control, 2011, 20 (3), pp.226. 10.1136/tc.2010.041574 . hal00605634

\section{HAL Id: hal-00605634 \\ https://hal.science/hal-00605634}

Submitted on 3 Jul 2011

HAL is a multi-disciplinary open access archive for the deposit and dissemination of scientific research documents, whether they are published or not. The documents may come from teaching and research institutions in France or abroad, or from public or private research centers.
L'archive ouverte pluridisciplinaire HAL, est destinée au dépôt et à la diffusion de documents scientifiques de niveau recherche, publiés ou non, émanant des établissements d'enseignement et de recherche français ou étrangers, des laboratoires publics ou privés. 


\section{Blood cigarettes: cigarette smuggling and war economies in central and eastern Africa}

Kristof Titeca ${ }^{1}$, Luk Joossens ${ }^{2}$, Martin Raw ${ }^{3}$

1. Research Foundation - Flanders, Institute of Development Policy and Management, University of Antwerp, Prinsstraat 13, 2000 Antwerp, Belgium

Kristof.Titeca@ua.ac.be

2. International Expert on Illicit Trade in Tobacco, Framework Convention Alliance, Brussels, Belgium

3. Special Lecturer, UK Centre for Tobacco Control Studies, Division of Epidemiology and Public Health, University of Nottingham

The Corresponding Author has the right to grant on behalf of all authors and does grant on behalf of all authors, an exclusive licence (or non exclusive for government employees) on a worldwide basis to the BMJ Publishing Group Ltd and its Licensees to permit this article (if accepted) to be published in Journal (insert name) editions and any other BMJPGL products to exploit all subsidiary rights, as set out in our licence (http://group.bmj.com/products/journals/instructions-for-authors/licence-forms).

Key words: Cigarette smuggling, war economy, tax evasion, tobacco control, Africa

Submitted: 07.06.10

Revision invited: 10.08 .10

Resubmitted: 10.11 .10

Word count: 4476

$\underline{\text { Author competing interests }}$

None.

Acknowledgements

KT's work on this project was supported by the Research Foundation, Flanders and the Institute for Development Policy and Management, University of Antwerp, to whom he is extremely grateful.

\section{Ethical review}

Field research was conducted by the first author. His research followed all necessary research protocols of both his funding institution (Research Foundation, Flanders) and his research institute (Institute of Development Policy and Management). As this research project did not involve trials on humans or animals, the codes of ethics in Belgium do not require a separate and specific ethics review for financing this project. However, the research institute of the first author verifies through its screening and monitoring procedures that relevant ethical standards are adhered to by the staff employed. 


\section{$\underline{\text { Abstract }}$}

Objective: Analyze cigarette smuggling practices in central and eastern Africa.

Methods: Primary data were gathered during long term qualitative field research in which about 400 interviews were conducted. Analysis of secondary sources included academic literature and reports from NGOs, multilateral organisations and the press.

Results: Our research suggests that the following factors play an important role in cigarette smuggling in eastern and central Africa: 1) government officials encounter difficulties monitoring the long and porous borders; 2) there is a general problem of corrupt government officials and particularly those who allow large-scale smugglers to operate; 3 ) criminal elements also play an important role in smuggling - cigarette smuggling has helped rebel groups to finance their activities, something illustrated through examples from the war economy in the eastern part of the Democratic Republic of Congo.

Conclusions: Our research suggests that cigarette smuggling in this region is not primarily the result of different taxation levels in neighbouring states, but rather the outcome of weak state capacity, high levels of corruption and the activities of criminals. Under these conditions smuggling cigarettes becomes an attractive option as taxation is so easily avoided. This explains why in the low-income countries in this study there are high levels of smuggling inspite of low cigarette prices. Comprehensive supply control and enforcement legislation, and cooperation at national, regional and global level are needed to tackle fraudulent practices facilitated by corruption at state level, and to effectively punish interaction between cigarette traders and rebel groups.

\section{What this paper adds}

Previous research on cigarette smuggling in Europe documents how smuggling is not primarily the result of different taxation levels but rather of fraud. This paper adds previously unavailable insights on how cigarette smugglers operate in eastern and central Africa through the use of qualitative and ethnographic data. These data allow detailed insight into the human mechanisms and consequences of smuggling, and the weak implementation enforcement mechanisms. They show how cigarette smuggling in Africa is the outcome of weak state capacity, high corruption levels, and the activities of rebel groups. 


\section{$\underline{\text { Introduction }}$}

Cigarette smuggling is a global phenomenon with a clear rationale: it is highly profitable and allows cigarette manufacturers to expand their markets. Major companies, such as British American Tobacco (BAT) and Philip Morris, have been accused of making use of smuggling networks. For example, research by the Center for Public Integrity accuses tobacco company officials at BAT and Philip Morris of being directly connected to organized crime in various countries (Hong Kong, Canada, Italy, United States) (1). Action on Smoking and Health (ASH) makes similar accusations against BAT (2). In July 2008 and April 2010 in Canada three tobacco companies pleaded guilty and admitted "aiding persons to sell or be in possession of tobacco products manufactured in Canada that were not packaged and were not stamped in conformity with the Excise Act" $(3,4)$.

Further, cigarette smuggling is detrimental to health policy $(5,6)$ and the WHO Framework Convention on Tobacco Control (FCTC) emphasises the importance for tobacco control of combating illicit trade (7). Smuggling undermines tax revenue and promotes corruption (8); by lowering price, consumption is increased (9); and smuggling promotes the development of new markets and better exploitation of old ones (10). For example, smuggling may lower the price of western tobacco brands, making them affordable to more people (9).

Map about here

Cigarette smuggling is a significant problem in Africa. In 2007 Africans smoked an estimated 400 billion cigarettes and the illicit market was estimated to be $15 \%$ of the total market (11), meaning over 60 billion smuggled cigarettes were consumed in Africa(12).

This paper examines cigarette smuggling in central and eastern Africa. As in other countries in Africa (13) and elsewhere (9), the high level of smuggling in central and eastern Africa has been used by cigarette manufacturers such as BAT to lobby for lower taxation $(14,15)$ and to influence public policy (16). Particularly in Uganda, BAT has argued that the high level of smuggling and consequent loss of revenue is caused by high taxation (17). However, research on cigarette smuggling in Europe $(9,18)$ showed that smuggling was not primarily caused by large price differences between different countries but "by fraud - by the illegal evasion of import duty"(9). The price argument therefore "grossly underestimates the pedigree and sophistication of parallel trading circuits" (19). 
This article illustrates the sophistication of this illegal trade in central and eastern Africa. It suggests that other factors, such as long and porous borders, government corruption and the presence of criminal elements play the major roles in cigarette smuggling, rather than tax/price differences. This paper s draws on qualitative and ethnographic data that reveal the human consequences of smuggling and the weaknesses of implementation mechanisms for controlling it.

Cigarette smuggling also offers opportunities for criminals such as rebel groups, who use it to finance their activities. A number of rebel groups are active, especially in the Democratic Republic of the Congo (DRC). These rebels are accused of serious human rights abuses, including mass murder, torture, rape and forced recruitment of children $(20,21,22)$. The second Congo war began in August 1998 in the DRC and was the biggest interstate war in African history, directly involving nine African countries. The war officially ended in July 2003 but a number of armed groups remained active in eastern DRC. Since 1998 millions of people have been displaced from their homes, and over 5 million people have died in the DRC through the direct and indirect consequences of the conflict (23).

\section{$\underline{\text { Methods }}$}

Researching illicit trade has inherent limitations (24) and little is known about cigarette smuggling in this region; for example, it is missing from a global smuggling analysis in the WHO Tobacco Atlas (25) and little has been written on the subject. Where written sources exist those concerned (such as governmental authorities) are reluctant to make the data (for example estimates of the amount of smuggling) available for security reasons (26). Primary data collection - field research - is also difficult, for obvious reasons: participants are secretive about their operations and distrustful of inquisitive outsiders; and it can be physically dangerous as smugglers can use violence and cooperate with rebel groups.

A crucial issue in this kind of research is therefore gaining respondents' trust, so we relied on anthropological methods. Anthropology involves long-term immersion in a community to gain acceptance and establish trust and rapport, and on qualitative methods like participant observation, interviews and surveys. It is a discipline which emphasises that human interactions can only be fully understood by including the context in which people live (27). This paper is based upon long-term field research on the organisation of smuggling networks in the Congo-Uganda-Sudan border region.

Using anthropological methods KT gained the trust of some Ugandan smugglers. During the initial phases of the field research in 2004/2005, KT made contact with a group of fuel smugglers who in turn introduced him to others in the wider smuggling economy $(28,29)$. Crucial in this kind of field research is cooperation with local people who facilitate entrance to these environments (27). KT therefore used two former smugglers (to some extent still engaged in the smuggling economy) as research assistants. Their cooperation was crucial in gaining the trust of actors in the regional smuggling economy. The fact that KT has been working with these traders since 2005 with no leaks of sensitive information also helped to establish his trustworthiness.

Interviewees Over 400 interviews were conducted over 6 years (2005-2010), $184(441 / 2 \%)$ with smugglers (Table 1). Interviews were also conducted with government and customs officials. Relationships of trust were established with several customs officials who became key informants. Others directly and indirectly related to the smuggling economy were 
interviewed, including politicians, journalists, intelligence officers, and civil society representatives. Interviews lasted between 30 and 150 minutes.

Table 1 about here

In order to avoid bias we interviewed people from different social backgrounds, different networks, and from both large-scale and small-scale smuggling operations. This allowed continuous cross-checking of information from different informants. For example, information from certain smugglers was cross-checked with information from other smugglers and also from customs officials, other government officials, 'legal' traders and various other actors. Similarly, information was cross-checked in different locations, as interviews were conducted in three main locations: 1) Arua, a major trading hub in northwestern Uganda close to the Congo and Sudan borders, where many smugglers are based; 2) Aru and Ariwara, major border trading towns in eastern Congo and central points in the regional smuggling economy (30); 3) the Uganda capital Kampala, with Ministry officials, intelligence officers, journalists and tobacco industry people.

Primary data Tape recorders were tried initially but because the interviews dealt with such sensitive and illegal issues they generated distrust and were abandoned. KT took detailed notes instead. These were transcribed immediately after the interviews and data categorised into themes such as 'confiscation practices', 'government involvement', 'rebel groups' and so on. In this way information on specific subjects could be compared and cross-checked in consequent interviews with the same and other actors. Thus the analysis proceeded using 'continuous review'. The research also relied on participant observation as KT spent time sitting in the 'offices' of smugglers, where deals were made and goods exchanged, and sometimes travelling with smugglers to border areas or other trading centres.

Secondary data Insights from the primary data were verified and supplemented through an analysis of secondary sources including reports from NGOs, multilateral organisations and newspapers. UN reports on the war economy in eastern DRC were especially useful. The UN appointed a Group of Experts which provided evidence on the complicity of state and nonstate actors in the war economy in Eastern DRC $(31,32)$. These reports also provided useful and well-researched information on the role of cigarette smuggling for rebel groups. With regards to newspaper reports, research was done in the archives of the most important Ugandan newspapers (Daily Monitor and New Vision) in their digital and physical archives, using the key words 'cigarette', 'Supermatch' and 'smuggling' over the last 10 years. These key words were in turn used for the global African news website 'allAfrica.com', which collects press reports from African newspapers.

Limitations Although interviews were conducted with a variety of actors and in a variety of locations, the contraband smuggling networks were the prime units of analysis. This led to a number of limitations. First, this study could not therefore rely on any systematic access to data, such as available written documents or quantitative information. Moreover, large scale surveys were not possible. Secondly, because this study focused on these smuggling networks, phenomena which were not directly part of these were not studied. For example, raw tobacco leaves are not part of these smuggling networks and were therefore not 
addressed. Thirdly, the qualitative field research was limited to one particular location, the Ugandan-Congolese-Sudanese border region.

\section{$\underline{\text { Results }}$}

\section{General smuggling patterns}

There is a particularly intense trade in smuggled cigarettes between Kenya, Uganda, Sudan and the Democratic Republic of Congo (DRC). Illicit cigarette trade in Uganda works in the following way: cigarettes are bought in Kenya, where they are produced, or arrive from further afield such as the Far East. Because these are destined for DRC or Sudan they do not pay any tax in Uganda as they are in transit. Nevertheless, they finally end up in Uganda. The most common scenario for doing so is that they first travel through Uganda to the DRC or Sudan and are then smuggled back in Uganda. The reason for this is that trucks in transit are monitored by the Ugandan customs authorities and on entry are sealed by them. Breaking the seal before leaving the country leads to major fines. Thus trucks first go to DRC and Sudan ( where the seal is broken) then cross back into Uganda. Alternatively but more risky, cigarettes are directly 'dumped' into Uganda. Whatever route is used, the result is the same: since they were in transit Ugandan tax was not paid so they are cheaper than legal, taxed cigarettes (3337). There is close cooperation between traders on different sides of the border in smuggling exported cigarettes back into Uganda (38-41). A good example was one of our informants, $\mathrm{O}$ :

$\mathrm{O}$ is a smuggler based in Arua who specializes in fuel and cigarettes. He works with two middlemen based in Mombasa, Kenya, who purchase these commodities for him. He also works with other middlemen who work at a more regional level, and physically travel with the cigarettes, accompanying the truck driver. $\mathrm{O}$ works together with Congolese trader A, whose papers he uses to obtain transit papers. Thus formally the cigarettes appear to be destined for Congolese trader A in Ariwara, DRC, because of which no Ugandan taxes are paid. However, either these goods never reach the DRC, and remain in Uganda, or they are smuggled back into Uganda. To smuggle goods back into Uganda, one of the middlemen hires 'transporters'. These are men who bring smuggled goods on their bicycles into Uganda, using smuggling routes (42).

O was fairly typical; most traders work similarly. For example, a Congolese cigarette trader told us, "I normally work with a Ugandan friend who also deals in cigarettes; he uses my name and then sells them in Uganda." (43)

Interviews with traders, customs officials and tobacco industry officials working at national level suggested that $15-20 \%$ of the Ugandan market is smuggled cigarettes (44). The annual Ugandan cigarette market is 2 billion cigarettes, thus annually between 300 and 400 million cigarettes are smuggled into Uganda, representing an annual tax loss of around US\$4 million (44).

Sudan plays a central role in the regional cigarette smuggling economy. This became clear when examining the amount of cigarettes being imported into the area. Southern Sudan has an estimated annual market (consumption) of 1 billion cigarettes (44), yet it is estimated that about 3 billion cigarettes annually enter the southern Sudan market (44). According to smugglers, journalists, government officials, and people in the tobacco industry, the 
remaining 2 billion are smuggled to neighboring countries: Uganda, Kenya, the Central African Republic, Chad and Ethiopia (44).

\section{Reasons for smuggling}

It could be argued that differences in taxation are the main reason for these smuggling patterns as tax in Sudan and Congo is lower than in Uganda. However, our field research suggested that other factors are more important. Firstly, even if taxation were equal in the different countries, in the context of limited enforcement capabilities, the illegal importation of untaxed cigarettes will still continue, particularly in places such as eastern DRC or southern Sudan where state capacity is very weak. As an assistant commissioner of the Uganda Revenue Authorities said with regards to the DRC (45) and Sudan: "there simply is no structured, credible and reliable administration to talk to, which makes it hard to prevent smuggling and track down smugglers" (46).

Secondly, customs and government officials highlighted their limited enforcement capacity, which prevented them fully monitoring the long and porous borders. A Ugandan customs official explained:

"The border with Congo and Sudan is very, very long, and there are many smuggling routes. It simply is impossible for us to control everything that crosses the border. So what do many people do? They take their bicycles, buy their goods in Congo and bring them to Uganda. There is not much we can do about this" (47).

Although this statement highlights an important dynamic, it should not be overestimated. Most of these routes are rather difficult to pass and only allow small consignments to pass on bicycles; trade in cigarettes is also considered risky by everyone involved as cigarettes are often confiscated and smugglers punished by government authorities. Contraband cigarettes are taken seriously by government officials. As one cigarette smuggler argued: "Smuggling cigarettes is not like smuggling motorcycles or other commodities. Smuggling cigarettes is much more dangerous! You can be jailed or killed for this!" (48). Not every trader wanted to take such risks. Thus connections with government officials were needed to safely smuggle cigarettes across the border. This was especially the case for larger quantities of cigarettes, which were often smuggled in vans or trucks and therefore used 'traditional' roads, which were subject to more state control. Only a handful of large-scale traders had the necessary connections with high-level actors in the customs authorities, army and government on the different sides of the borders (ie. with Ugandan, Congolese and Sudanese officials), which guaranteed safe passage of the commodity. As one customs official explained:

"When big consignments of goods want to pass, they (the large-scale smugglers) contact our boss, who then tells us: when you see this and this truck coming, you have to let it pass. Of course, he also gives us something little appreciation for this." (49)

Customs officials also consistently pointed to the involvement of high-level government authorities in cigarette smuggling $(50,51)$. Connections with governmental authorities were needed to smuggle large quantities of cigarettes across the border, and government officials only work with a limited number of traders. As one customs officials explained: "It is better to work with those you know than with those you do not know" (52). These factors particularly explain why the percentage of smuggled cigarettes in this region is not higher: smugglers 
believed that cigarette smuggling is strongly punished by government authorities and only a handful of traders have the necessary government connections.

In this situation traders often paid no taxes at all: as explained above, tax was not paid on the cigarettes in Uganda, and often not on arrival in Sudan or DRC either, and they are then smuggled back into Uganda. As one large-scale middleman argued: "We often do not pay taxes in Sudan or Congo: we simply pay some Kitu Kidogo (bribe). We then sell them there or we bring them back into Uganda." (53)

Our interviewees told us that cigarette smugglers did not limit their activities to cigarettes alone, but also included other profitable contraband such as fuel and batteries. This became clear during the long-term participant observation with the smugglers who were continuously dealing with other contraband goods, being well-informed about the dynamics of supply and demand in specific locations. As one smuggler explained: "it is too dangerous to focus on one commodity. For example, I myself mostly deal in cigarettes, because they are very profitable. However, the market can suddenly become flooded with cigarettes, because of which I am stuck with my cigarettes. It therefore is better to trade in other commodities as well!" (54)

Our interviews and participant observation revealed that for bigger traders illegal minerals were also part of this regional trade:

Ugandan smuggler $\mathbf{J}$ is one of the biggest traders of north western Uganda. His main commodities are cigarettes, batteries and minerals. He buys gold in eastern DRC, sells it in Kampala, Mombasa, Nairobi or the Far East, where he buys other manufactured goods such as cigarettes and batteries. These are in turn exported to eastern DRC, where he buys minerals (55).

$\mathbf{J}$ was representative of many other bigger traders engaged in illegal commodities. The smuggling networks trade in a variety of goods; cigarettes are at the centre but they are connected to other goods such as smuggled minerals, which makes them ideal for other criminal organizations - such as rebel groups - to tap into the trade. This is what happened in eastern Congo, as explained in the next section.

\section{Cigarette smuggling and the war economy in eastern DRC}

The presence of criminal organizations, such as rebel groups, facilitates cigarette smuggling, and smuggling played a direct role in the war economies in north eastern DRC, bordering Uganda and Sudan. From 2003 to 2005 the rebel group Armed Forces of the Congolese People (Forces Armées du Peuple Congolais, FAPC) was in power in some areas of north eastern DRC, controlling the important trading towns in the area (31). This rebel group financed its activities in several ways. First, it controlled taxation policies in the area. Second, it controlled the extraction of minerals in the area (56). Third, it financed itself through the "monopolistic control over key export trades" (32). Although international reports (56) mainly focus on the trade in minerals, another key export trade is the trade in cigarettes, especially the Supermatch brand manufactured in Kenya (31).

As demonstrated above, these smuggling networks are organized on a regional basis, something which the rebel group was not able to control. They could only control one part of this trading network and therefore had to rely on a range of actors in structuring this regional trade. The rebels therefore directly cooperated with the large-scale traders mentioned above. 
The UN reports accuse Ugandan and Congolese traders of helping the rebel group control regional networks of smuggled goods such as cigarettes $(31,32)$. The profits of this trade were shared between the rebel group and the traders (57).

The coalition of smugglers and rebels had a monopoly on the sale of cigarettes in the area; in which Supermatch cigarettes played an important role. It cooperated with a number of local traders, who shared the profits. Other actors wanting to enter this market had to act through this coalition. According to former rebel administrators, smugglers and customs officials, the rebels pushed out other Supermatch traders and had privileged arrangements with the Supermatch manufacturers: "orders were placed upfront at the Kenya factory and they made sure they had a monopoly on Supermatch: they were in charge here, and they did not fear to use their guns. The other Supermatch traders had no choice but going away or cooperating with Jérôme" (58). A Congolese civil servant who is a former rebel administrator, explained: "the rebel leadership used their position to engage themselves in this business and push out other traders" (59).

The coalition also controlled the smuggling of Supermatch cigarettes back into Uganda, as tax evasion was made easier through cooperation with officials on both sides of the UgandaCongo border $(31,32)$. For example a UN Group of Experts report showed that at the Ugandan customs points "normal citizens were usually inspected and registered, whereas FAPC members were registered inadequately or not at all" (31). The report also shows how the rebel movement benefits from negligent customs supervision, in which the FAPC "benefits directly from unchecked imports from Uganda, which could readily contain arms, ammunition or other military supplies" (32). These factors greatly eased cigarette smuggling.

Interviews with smugglers also made clear that smuggling was much easier during the FAPC regime. One smuggler explained: "During Jerome's time, things were so much easier: you received direct transport and escort! There was no payment on the road, and you were always protected! You did not even have to hide your goods." (60) In June 2005, for example, the Congolese army confiscated Supermatch cigarettes smuggled into the Congo with an excise tax value of approximately $\$ 230,000$. In reaction, local Ugandan army officers threatened to intervene militarily if the cigarettes were not released by the local authorities. The cigarettes were handed back to the smugglers (32).

Thus cigarettes allowed FAPC to make profits in two locations: some of these illegal cigarettes were sold on the Congo side of the border and some were smuggled back into Uganda. As the UN Group of Experts argued, not only did this smuggling network sustain the rebel movement, it also created a permissive environment for the trafficking of weapons in the region (32). The rebel movement was also engaged in major human rights abuses such as summary executions, executing and torturing political opponents, arbitrary detention and torture, tolerating abuses by business allies, and the abduction of children to use as child soldiers $(56,61)$. Thus the income derived from trading activities, including cigarette smuggling, financed a movement that committed human rights abuses.

In summary, the cigarette trade helped finance FAPC and the war economy also proved extremely advantageous for the Supermatch brand: it gave them a strong sales position in the areas controlled by the rebel force, and it not only generated short-term financial gain but also long-term corporate advantage, as the product was introduced to large segments of the population. During the rebel regime Supermatch cigarettes were widely available and very cheap. As argued in the introduction, in the low-income context of Uganda and the DRC price 
is a key factor for cigarettes. During the FAPC regime Supermatch were sold at an incredibly low price, $\$ 0.37$ per packet, thus increasing consumption.

\section{The Supermatch brand}

Supermatch is a very popular cigarette brand among smugglers in this region and the FAPC relied on them to finance its activities. Supermatch has been a particularly controversial brand in Uganda. Manufacturers Mastermind Tobacco have been accused of being involved in various tax evasion scandals (62). In April 2000 its factory was closed down by the Uganda Revenue Authorities (URA) on suspicion of tax evasion (63). In October 2002 Mastermind Tobacco was raided and closed by the Ugandan authorities, accused of the production of counterfeit cigarettes. Press reports claimed that Supermatch cigarettes sold on the Ugandan market with a "Made in Uganda" label were coming from Kenya but packed in Uganda (64). Moreover the owner of Mastermind Tobacco, Franco Mugabe, was accused by the United Nations Group of Experts of being directly involved in smuggling cigarettes with the rebel movement FAPC. A UN report identifies him as one of the Ugandan businessmen participating in the smuggling of Supermatch cigarettes (32).

Tribert Ayabatwa Rujiguro, the CEO of the Mastermind group (producing Supermatch) has also been accused of being involved in a number of cases of tax evasion. For example, the South African Revenue Services (SARS) halted the operations of his factory Mastermind South Africa in November 2006 in a $\$ 7.8$ million (57 million Rand) fraud case (65). There are also press reports of tax evasion on Supermatch cigarettes in some Congo provinces (65). Finally, press reports claimed how in January 2009, nine containers of Supermatch cigarettes produced by Mastermind Tobacco were confiscated as contraband in Ghana. The cigarettes were manufactured in the United Arab Emirates, stamped with fake "Sale in Ivory Coast' stamps and destined for Mali, where, it is presumed, they were not sold $(66,67)$. Lastly, the importance of Supermatch is also reflected in the legal sale figures. The table below shows the legal sales of Mastermind and BAT in Uganda (BATU).

Table 2 about here

This table clearly shows how BAT and Mastermind (Supermatch) are the two main players in the legal Ugandan market. The fact that Supermatch cigarettes played an important role in regional smuggling networks (69) therefore particularly caused problems for its main competitor, BAT. Supermatch is a particularly cheap cigarette, targeting the lower end of the market. BAT - largest corporate taxpayer in Uganda - is naturally also targeting this lower market segment. However, no similar evidence of involvement of BAT in smuggling practices was found, and BAT brand cigarettes were also less present in the smuggling networks in this region.

\section{$\underline{\text { Discussion }}$}


Some governments have been influenced by the argument that tax/price increases lead to higher levels of smuggling (18). This research illustrates another key factor explaining why cigarette smuggling is often higher in low-income countries where prices are lower: corruption and weak state capacity. In this context cigarette smuggling is an attractive option as tax can so easily be avoided, not only for traders but also for other criminal elements in the region, including rebel groups. As there are 'blood diamonds,' so we would label smuggled cigarettes in this region 'blood cigarettes': cigarettes responsible for financially sustaining rebel groups responsible for grave breaches of human rights.

These smuggling practices also undermine effective health policies by increasing consumption through low price, low income smokers being particularly sensitive to price (70,71). In Uganda and DRC per capita GDP is respectively just \$1,149 and \$330 (72-74).

There is therefore a need for comprehensive supply control and enforcement legislation to tackle this behavior, at a corporate level and through criminal prosecution of individuals, which might act as a deterrent for interaction with rebel groups. However such legal mechanisms are particularly difficult in the context of weak states such as Uganda, DRC and Sudan, who might benefit from technical assistance with tasks such as drafting legislation, developing and maintaining tracking mechanisms, and investigation and prosecution of alleged offenders (13).

The best option for effective international action is the WHO FCTC and its illicit trade protocol, currently being negotiated. The protocol seeks to enhance international cooperation, and to introduce supply control measures such as licensing, tracking and tracing, record keeping and due diligence. These measures could facilitate investigations into smuggling operations and make the industry liable for controlling the supply chain. The global scope and multifaceted nature of the illicit tobacco trade requires a coordinated, international response.

\section{References}

1. International Consortium of Investigative Journalists. Tobacco companies linked to criminal organizations in lucrative cigarette smuggling. The Centre for Public Integrity, 3 March 2001. http://projects.publicintegrity.org/Content.aspx?context=article\&id=351 (accessed 19 Dec 2009)

2. UK House of Commons. Select Committee on Health. Second Report. The Tobacco Industry and the Health Risks of Smoking. 14 June 2000 www.parliament.the- 
stationery-office.co.uk/pa/cm199900/cmselect/cmhealth/27/2707.htm (accessed 20 Dec 2009).

3. Canada Revenue Agency. BACKGROUNDER: Federal, provincial and territorial governments enter into civil settlement agreements with two tobacco companies. Press release. www.cra- arc.gc.ca/nwsrm/rlss/2010/m04/nr100413b-eng.html (accessed October 2 2010).

4. JTI-Macdonald Corp. JTI-Macdonald Corp. reaches an agreement regarding illicit trade of cigarettes in Canada. Press release. 13 April 2010. www.newswire.ca/en/releases/archive/April2010/13/c2046.html (accessed 02 October 2010).

5. Joossens $\mathbf{L}$, Raw M. Turning off the tap: the real solution to cigarette smuggling. Int $J$ Tuberc Lung Dis 2003;7:214-22.

6. Collin J, LeGresley E, MacKenzie R, Lawrence S, Lee K. Complicity in contraband: British American Tobacco and cigarette smuggling in Asia. Tob Control 2004;13:104-111.

7. World Health Organization. Framework Convention on Tobacco Control. Geneva, World Health Organization, 2003. www.who.int/tobacco/areas/framework/final text/en (accessed 05 April 2010)

8. Campaign for Tobacco Free Kids. Illegal pathways to illegal profits: the big cigarette companies and international smuggling. Washington DC, Campaign for Tobacco Free Kids, 2001. http://tobaccofreekids.org/campaign/global/framework/docs/Smuggling.pdf (accessed 19 Dec 2009).

9. Joossens L, Raw M. Cigarette smuggling in Europe: who really benefits? Tob Control 1998;7:66-71.

10. Gilmore AB, McKee M. Moving East: how the transnational tobacco industry gained entry to the emerging markets of the former Soviet Union - part I: establishing cigarette imports. Tob Control 2004;13:143-150.

11. Framework Convention Alliance (FCA). 'How big was the global illicit tobacco trade problem in 2006?', Presentation for the second session of the conference of the parties to the WHO FCTC June 30-July 6, 2007 Bangkok, Thailand: 5. www.fctc.org/dmdocuments/fca-2007-cop-illicit-trade-how-big-in2006-en.pdf (accessed 07 June 2010)

12. United Nations Office on Drug and Crime. Transnational Trafficking and the Rule of Law in West Africa: A Threat Assessment. Vienna: United Nations Office on Drug and Crime, July 2009: 28. http://www.unodc.org/documents/data-andanalysis/Studies/West_Africa_Report_2009.pdf (accessed 12 Dec 2009)

13. LeGresley E, Lee K, Muggli M E, Patel E, Collin J, Hurt R D. British American Tobacco and the "insidious impact of illicit trade" in cigarettes across Africa. Tob Control 2008;17:339-346.

14. Olanyo J. Smuggling costs government multi-billion tax losses. The Monitor 19 July 2005.

15. Mugabi F. Smuggled cigarettes flood Arua. New Vision 13 September 2005.

16. Patel P, Collin J, Gilmore AB."The law was actually drafted by us but the Government is to be congratulated on its wise actions": British American Tobacco and public policy in Kenya. Tob. Control. 2007;16: 1-8.

17. Wadri P. Forged URA stamps to alarm firms. The Monitor 8 June 2005.

18. Joossens L, Merriman D, Ross H, Raw M. How eliminating the global illicit cigarette trade would increase tax revenue and save lives. Paris: International Union Against Tuberculosis and Lung Disease, 2009. 
19. Meagher K. The hidden economy: informal and parallel trade in Northwestern Uganda. Review of African Political Economy 1990;47:64-83.

20. Human Rights Watch. Ituri: "Covered in Blood". Human Rights Watch, New York, July 2003.

21. International Crisis Group. The Congo's Transition is Failing: Crisis in the Kivus. International Crisis Group Africa Report No 91, 30 March 2005.

22. International Crisis Group. Scramble for the Congo: Anatomy of an Ugly War. International Crisis Group Africa Report $N^{\circ} 26$, December 2000.

23. Coghlan B, Ngoy P, Mulumba F, Hardy C, Nkamgang V, Stewart T, Lewis J, Brennan R. Mortality in the Democratic Republic of Congo. An Ongoing Crisis. International Rescue Committee. Burnet Institute. http://www.theirc.org (accessed 15 September 10).

24. Ellis S, Macgaffey J. Research on Sub-Saharan Africa's unrecorded international trade: some methodological and conceptual problems. African Stud Rev 1996;2: 19-41.

25. Mackay J, Ericksen M. The Tobacco Atlas. Geneva: World Health Organization, 2002: 55. http://www.who.int/tobacco/statistics/tobacco atlas/en/ (accessed 16 Jan 2010)

26. Joossens L, Merriman D, Ross H, Raw M. How eliminating the global illicit cigarette trade would increase tax revenue and save lives. Paris: International Union Against Tuberculosis and Lung Disease, 2009.

27. Ellis S, Macgaffey J. Research on Sub-Saharan Africa's unrecorded international trade: some methodological and conceptual problems. African Stud Rev 1996;2:19-41.

28. Titeca K. Les OPEC boys en Ouganda, trafiquants de pétrole et acteurs politiques. Pol Africaine 2006;103:143-159.

29. Titeca K, Vervisch T. The dynamics of social capital and community associations in Uganda: linking capital and its consequences. World Dev 2008;11:2205-2222

30. Titeca K. The changing Cross-border Trade Dynamics between North-western Uganda, North-eastern Congo and Southern Sudan. Crisis States Working Paper 63 series 2, 2009. London: London School of Economics and Political Science, Crisis States Research Centre. http://www.crisisstates.com/download/wp/wpSeries2/WP63.2.pdf

31. United Nations. Report of the Group of Experts in accordance with paragraph 6 of Security Council resolution 1552 (2004) of 27 July 2004. 25 January 2005.

32. United Nations. Report of the Group of Experts in accordance with paragraph 22 of Security Council resolution 1596 (2005). 26 July 2005.

33. Munaita P. Industry moves to stub out illicit cigarette trade. The Eastafrican 06 December 2005

34. Balagadde S. URA seizes Sh78 million cigarettes. New Vision 18 August 2008.

35. Mugabi F. URA seizes smuggled cigarettes in Arua. New Vision 23 November 2006.

36. New Vision. Smuggling is a big threat to the local industries. New Vision 10 June 2009.

37. New Vision. URA captures smuggled cigarettes. New Vision 15 November 2009.

38. Numerous court cases, reports and articles are testify to this regional dynamic. Uganda: Commercial Court. Uganda Revenue Authority V Congo Tobacco Co. Ltd ( HCT-00-CC-CA-03-2006) [2007] UGCommC 21 (27 February 2007). http://www.saflii.org/ug/cases/UGCommC/2007/21.html (accessed 12 Dec 2009).

39. Obwana, M, Ayoki, M. Illicit Trade in East Africa. Institute of Policy Research and Analysis. May

2005 . http://www.ipraa.org/papers/IPRA\%20WP08\%20Illicit\%20trade\%20EA.pdf (accessed 24 Jan 2010). 
40. Kasita I. \$ 105 million lost in smuggling. New Vision 2 December 2009.

41. Mugabi F. URA impounds smuggled cigarettes. New Vision 28 April 2009.

42. Analysis based on fieldwork with smuggler O. from 2005-2010 by KT.

43. Interview. Congolese cigarette trader, Ariwara (Congo), 03 August 2010.

44. Interviews. Cigarette industry officials, Uganda Revenue Authority Officials, researchers, journalists, 2009-2010 (all wish to remain anonymous).

45. Tegera A, Johnson D. Rules for sale: formal and informal cross-border trade in Eastern DRC. A Pole Institute Report. Regards croises. Revue trimestrielle N ${ }^{\circ} 19$ bis. Goma, May 2007.

46. Interview. Assistant commissioner Uganda Revenue Authorities Kampala (Uganda), 08 February 2010.

47. Interview Ugandan customs official Arua (Uganda), 14 February 2008.

48. Interview Ugandan cigarette smuggler, Arua (Uganda), 30 January 2008.

49. Interview Ugandan customs official Arua (Uganda), 28 January 2010.

50. Nabyama P. High tax on cigarettes could raise smuggling. East African Business Week 28 April 2008.

51. Fjeldstad OH. Corruption in tax administration. Lessons from institutional reforms in Uganda. In: Rose-Ackerman, S. ed. International Handbook on the Economics of Corruption. Edward Elger Press 2006.

52. Interview Ugandan customs official, Arua (Uganda), 04 February 2008.

53. Interview two Ugandan smugglers, Arua (Uganda), 05 February 2010.

54. Interview Ugandan smuggler, Arua (Uganda), 28 September 2008.

55. Analysis based on fieldwork on smuggler J. from 2006-2010 by KT

56. Human Rights Watch. The curse of gold. Human rights watch: 1 June 2005.

57. Titeca K. Conflict and state-reconstruction: the FAPC and cross-border trade in the Congolese-Ugandan borderlands, unpublished paper, forthcoming.

58. Interview Ugandan customs official Arua (Uganda), 05-08-09.

59. Interview Congolese former rebel administrator, Ariwara (Congo), 30-07-09.

60. Interview Ugandan smuggler Arua (Uganda), 16 April 2007

61. United Nations. General Assembly, Security Council. Children and armed conflict. A/61/529-S/2006/826 (2006). 26 October 2006.

62. Kaheru S. Mastermind to pay URA dues. The Monitor 15 July 2000.

63. New Vision. Mastermind free to operate. New Vision 27 April 2000.

64. Obwona M, Ayoki M. Illicit Trade in East Africa. Institute of Policy Research and $\begin{array}{llll}\text { Analysis } \quad \text { Working } & \text { Paper }\end{array}$ http://www.ipraa.org/papers/IPRA\%20WP08\%20Illicit\%20trade\%20EA.pdf (accessed 13 December 2009).

65. Tobacco Control in Africa. RDC, Rwanda, South Africa: Mastermind Tobacco CEO accused of evading taxes and financing the war. January 08, 2009. http://blogsofbainbridge.typepad.com/africa/2009/01/ (accessed 13 December 2009).

66. Wilson K. Terrorism and Tobacco - how cigarette smuggling finances Jihad and insurgency worldwide. Center for Public Integrity, 2009. http://www.thecuttingedgenews.com/index.php?article=11427 (accessed 13 December 2009).

67. United Nations Office on Drugs and Crime (UNDOC). Transnational trafficking and the rule of law in West-Africa: a threat assessment. July 2009. http://www.unodc.org/documents/data-andanalysis/Studies/West Africa Report 2009.pdf (accessed 12 December 2009)

68. BAT Uganda, cited in Obwona M, Wasswa F, Nabwwayo V. Taxation of the Tobacco Industry in Uganda. The case for excise duty on cigarettes. Economic Policy 
$\begin{array}{lllll}\text { Research } & \text { Centre, } & \text { Research } & \text { Series }\end{array}$

http://www.eprc.or.ug/pdf_files/researchseries/series44.pdf (accessed 30 August 2010)

69. Fieldwork data KT 2005-2010

70. West R, Townsend J, Joossens L, Arnott D, Lewis S. Why Combating Tobacco smuggling is a priority. BMJ 2008;337:1028-1029.

71. Townsend J, Roderick P, Cooper J. Cigarette smoking 13 by socioeconomic group, sex and age: effects of price, income and health policy. BMJ 1994;309:923-7.

72. International Monetary Fund. World Economic Outlook Database. October 2009. http://imf.org/external/pubs/ft/weo/2009/02/weodata. (accessed 22 Dec 2009).

73. Ugandan Ministry of Finance, Planning, Economy and Development. Poverty Eradication Action Plan Uganda 2004/5 - 2007/8. http://siteresources.worldbank.org/INTPRS1/Resources/UgandaPEAP(2005-Apr).pdf (accessed 22 December 2009).

74. Marivoet W. Decentralising the Challenges of Poverty Reduction in the DRC in: Marysse, S. et al. (eds.) L'Afrique des grands lacs: annuaire 2008-2009. Paris, Harmattan, 2009. 


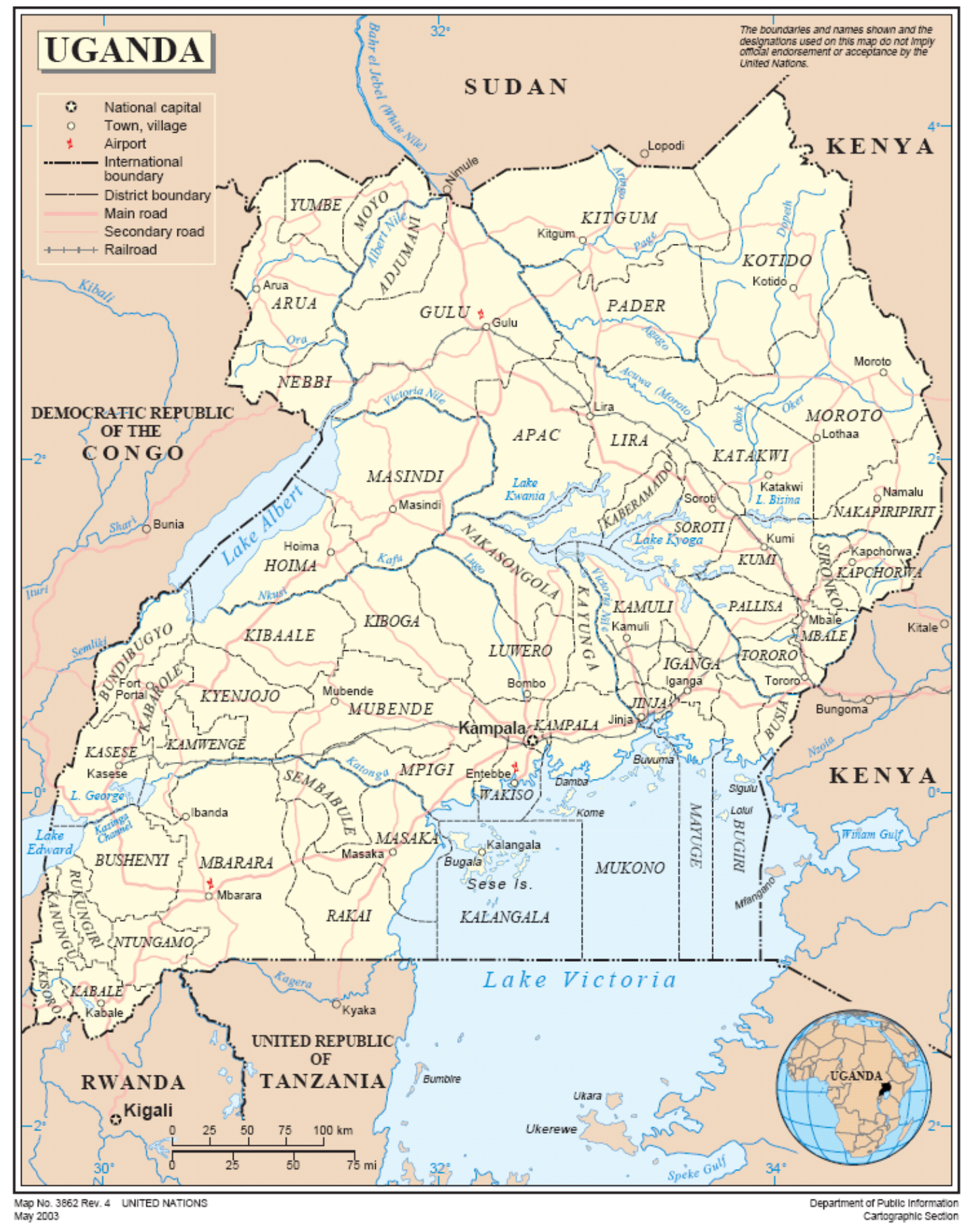

Table 1. Number and type of interviews 


\begin{tabular}{|l|l|}
\hline Category of interviewee, location of interview & Number \\
\hline Ugandan smugglers, Arua (Uganda) & 155 \\
\hline Ugandan customs officials, Arua (Uganda) & 44 \\
\hline Ugandan community-based association representatives, Arua (Uganda) & 32 \\
\hline Ugandan 'legal' traders, Arua (Uganda) & 26 \\
\hline Congolese smugglers, Aru and Ariwara (DRC) & 23 \\
\hline Ugandan elders, Arua (Uganda) & 19 \\
\hline $\begin{array}{l}\text { Ugandan politicians (members of parliament and district councillors), Arua and } \\
\text { Kampala (Uganda) }\end{array}$ & 14 \\
\hline Ugandan journalists, Kampala (Uganda) & 11 \\
\hline Ugandan former smugglers, Arua (Uganda) & 10 \\
\hline $\begin{array}{l}\text { Congolese NGO and community-based association representatives, Arua } \\
\text { (Uganda) Aru and Ariwara (DRC) }\end{array}$ & 10 \\
\hline Ugandan tobacco industry actors (company managers), Arua and Kampala & 8 \\
\hline Ugandan ministry officials, Kampala (Uganda) & 7 \\
\hline Congolese government officials, Aru and Ariwara (DRC) & 6 \\
\hline Intelligence officers, Kampala & 5 \\
\hline $\begin{array}{l}\text { Consultants (working on Northern Uganda for international development } \\
\text { organisations), Kampala (Uganda) }\end{array}$ & 4 \\
\hline Congolese customs officials, Ariwara (DRC) & 4 \\
\hline Ugandan 'legal' traders, Kampala (Uganda) & 4 \\
\hline Ugandan smugglers, Kampala (Uganda) & 3 \\
\hline Congolese 'legal' traders, Aru and Ariwara (DRC) & 3 \\
\hline Sudanese smugglers, Arua (Uganda) & 3 \\
\hline Sudanese civil society representatives, Arua (Uganda) & 3 \\
\hline Ugandan journalists, Arua (Uganda) & 3 \\
\hline Ugandan police officers, Arua (Uganda) & 3 \\
\hline Congolese tobacco industry actors (company managers), Ariwara (DRC) \\
\hline Diplomat, Kampala (Uganda) & $\mathbf{4 0 4}$ \\
\hline Total number of interviews & \\
\hline & \\
\hline
\end{tabular}

Table 2. Legal cigarette sales in Uganda (millions of sticks) (68) 


\begin{tabular}{|l|l|l|l|l|l|l|l|}
\hline & 1998 & 1999 & 2000 & 2001 & 2002 & 2003 & 2004 \\
\hline BATU & 1773 & 1582 & 1277 & 1035 & 1054 & 1240 & 1251 \\
\hline Mastermind (Supermatch) & 90 & 119 & 112 & 155 & 185 & 167 & 231 \\
\hline Total Uganda sales (all manufacturers) & 1865 & 1709 & 1400 & 1206 & 1273 & 1422 & 1694 \\
\hline
\end{tabular}




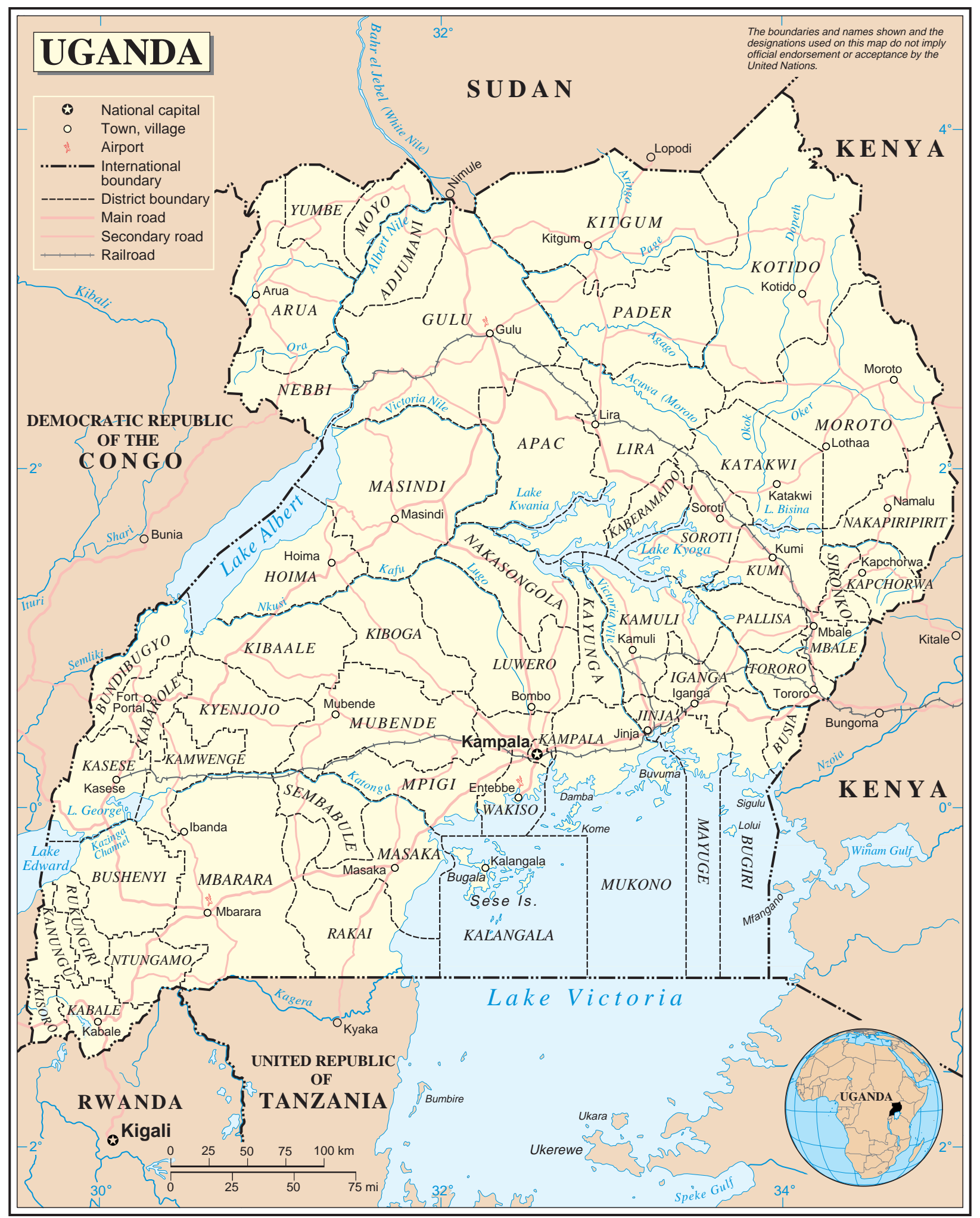

Map No. 3862 Rev. 4 UNITED NATIONS 